\title{
Article
}

\section{Optimal Configuration and Sizing of Seaport Microgrids including Renewable Energy and Cold Ironing - The Port of Aalborg Case Study}

Nur Najihah Abu Bakar ${ }^{1,2}$, Josep M. Guerrero ${ }^{1,}{ }^{*}$, Juan C.Vasquez ${ }^{1}$, Najmeh Bazmohammadi ${ }^{1}$, Muzaidi Othman ${ }^{2}$, Brian Dalby Rasmussen ${ }^{3}$, and Yusuf A. Al-Turki ${ }^{4}$

\footnotetext{
1 Center for Research on Microgrids (CROM), AAU Energy, Aalborg University, 9220 Aalborg East, Denmark; nurnbab@energy.aau.dk; joz@energy.aau.dk; juq@energy.aau.dk; naj@energy.aau.dk

2 Faculty of Electrical Engineering Technology, University Malaysia Perlis (UniMAP), Kampus Pauh Putra, 02600 Arau, Perlis, Malaysia; nurnajihah@unimap.edu.my; muzaidi@unimap.edu.my

3 Port Facility and Environment Management, Port of Aalborg, Langerak 19, 9220 Aalborg, Denmark; bdr@portofaalborg.com

4 Center of Research Excellence in Renewable Energy and Power Systems, Department of Electrical and Computer Engineering, Faculty of Engineering, K. A. CARE Energy Research and Innovation Center, King Abdulaziz University, Jeddah 21589, Saudi Arabia
}

*Correspondence: joz@energy.aau.dk

\begin{abstract}
Microgrid is one of the promising green transition technologies that will provide enormous benefit to the seaport, as a solution to the major concerns in this sector, namely energy crisis, economical and environmental pollution. However, finest design of the microgrid is a challenging task considering different objectives, constraints and uncertainties involved. To ensure the optimal operation of the system, determining the right configuration framework and size for each component in the seaport microgrid at the minimum cost is a vital decision at the design stage. This paper aims to design a hybrid system of seaport microgrid with optimally sized component . The selected case study is the Port of Aalborg, Denmark. The proposed grid-connected structure consists of renewable energy sources (photovoltaic system and wind turbines), an energy storage system and cold ironing as seaport' loads. The architecture is then optimized by utilizing HOMER to meet the maximum load demand by considering a few parameters such as solar global horizontal irradiance, temperature and wind resources. Then, the best configuration framework is analyzed in terms of economic feasibility, energy reliability and environmental impact.
\end{abstract}

Keywords: Cold ironing, energy management system, optimal sizing, renewable energy sources, seaport microgrids, maritime

\section{Introduction}

Conventionally, energy sources that generate electricity to supply the maritime loads is fossil fuels based. In fact, many users worldwide, across all industries, still rely on this traditional method of obtaining energy. The main sources of power come from the utility grid and diesel generators, constantly emitting greenhouse gas emissions. Ironically, the energy sector is encountering the depletion of primary energy seeing that load demand is always ahead of the power generation.

With growing awareness of the jeopardy from resource depletion issues and environmental pollution, many ports around the world are taking an action leading toward a zero carbon footprint goal. Reference [1] in their research, indicated that Jurong Port in Singapore built a large solar power plant capable of supplying $60 \%$ of port's load. In 2019 , 
Denmark showed a remarkable result by generating half of its electricity from wind and solar power [2]. The advantage of climate's constant breezes and bluster in this country makes the wind turbine practical to use and well established. Danish maritime industry has set a target of $70 \%$ reduction in $\mathrm{CO}_{2}$ emission by implementing wind energy and energy management systems in the ports [3].

Ports worldwide have different sizes, operations, geological and geographical features, and variety of energy sources that will affect the final load demand as well as energy production. The urge to use alternative clean energy resources makes microgrids the best solution for future green seaports. Besides, recent advances in energy storage solutions facilitate the flexible operation and efficient control of seaport microgrids. Energy storage systems (ESS) can be used to store the excess energy from RESs and supply the load during peak hours or under emergency operating conditions (i.e. system fault and energy shortage).

Despite the fact that microgrids are widely used in different land applications, there are limitations of its real implementation in the seaport sector. This situation makes it a good opportunity to introduce microgrids into the seaports but at the same time, it is also difficult to access the references in terms of their requirements, optimal design, stability, and maintenance needs. Especially during the design phase, it is a complicated task to find the optimal design of the seaport microgrid to determine the proper sizing for each component in the microgrid and a compatible configuration. Therefore, this research work presents a simulation-based method using the HOMER optimizer to analyze the seaport microgrids configuration and its sizing in terms of cost minimization, energy production, and environmental impact.

Seaport microgrid in this paper refer to the integration microgrid power system into one of the seaport application that is known as cold ironing. The evolvement of trading activities worldwide increasing the reliance on the maritime transportation. This situation resulting into the growing concern on the worse carbon footprint from ships when docked at ports [4]. When a ship is at berth, the auxiliary engine keep on to supply onboard power supply. It consume a huge amount of heavy diesel oil depend on the berthing hours and ship's power requirement that emitting hazardous gases and degraded air quality. Here, come the electrification alternative to reduce the air emission during berthing by using cold ironing.

Cold ironing is an emission-free technology that prevents vessels from continuously burning fossil fuels by supplying onboard electric power directly from the onshore grid [5]. The auxiliary engine is turned off completely (cold process), but the ship can continue to operate normally since switchboard draw the power from the shore side (ironing). There are three types of cold ironing topologies: 1) centralized cold ironing and 2) distribution cold ironing and 3) DC distribution cold ironing [6]. According to D.Colarossi and P. Principi [7] , the amount of ship power plant varies with type of the ship, with typical distributed power of $400 \mathrm{~V}$. While on the shore side, generally it is connected with Medium Voltage (MV) of $6.6 \mathrm{kV} / 11 \mathrm{kV}$. In order to step down or step up the desired voltage level, transformer play as a vital role in this system. Nevertheless, there are some obstacles in term of frequency where most of the port using $60 \mathrm{~Hz}$ meanwhile Europe and Asian's port using $50 \mathrm{~Hz}$ [5]. When the frequency on the shore side and the frequency on the ship do not meet, a frequency converter is required. Figure 1 illustrate the typical cold ironing connection from shore side to the shipside.

One of the challenges for port operation is the uncertainty in load burden, where the traffic density of ships berthing can suddenly increase. Another scenario considered is the possibility of a few large ships with large loads docking at the same time where the load demand might be larger than the available supply. Energy security to ensure reliable port operation will be in low efficiency if cold ironing solely depend on the grid supply. These challenges is a motivation in this paper for the seaport microgrid idea. 


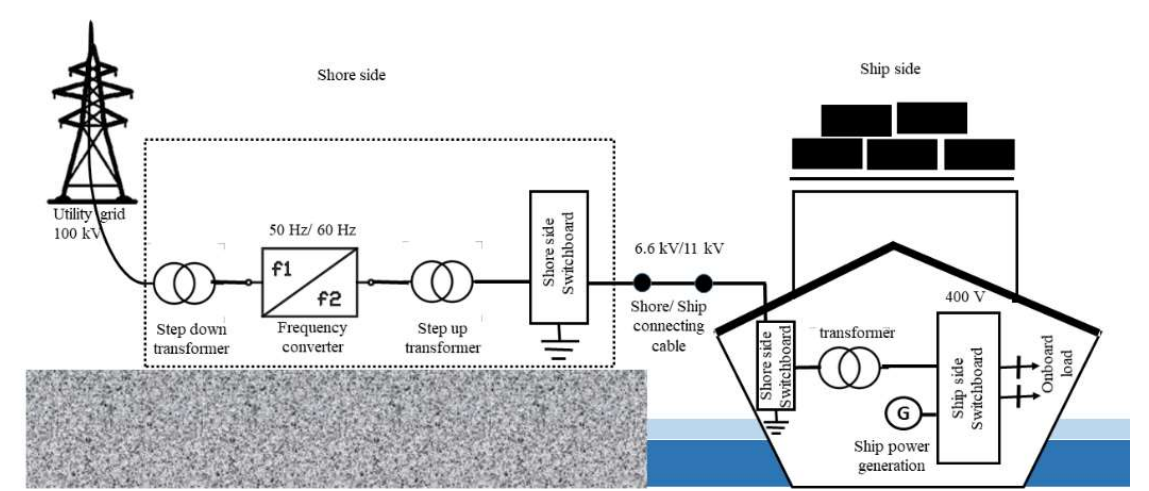

Figure 1. Typical cold ironing system from shore side to seaside.

The emerging concept of the microgrid into the cold ironing is beneficial for maritime industry. Collaboration between these two electrification give an advantage to the several aspect in term of the energy resiliency, emission control and economic. Cold ironing can cause to the power disturbance if the continuous high demand from the ships during berthing over the supply that cold ironing can provide. In the case of power break down, many of the port operations will be affected leading to losses of billion dollars. In this case, local distributed energy from seaport microgrid capable to offer the energy in the time of stress [8]. It increase the energy security and resiliency to the cold ironing facility. In addition, seaport microgrid also can enhance more electrification to the port by adding cold ironing facilities in which grid unable to support. In term of the emission control, cold ironing itself eliminates a portion of emission compare to the conventionally using auxiliary engines while docking [9]. Seaport microgrid enhance more pollution free by zero carbon generation from renewable energy. Besides, seaport microgrid is the economically efficient to reduce port's cost operation, decrease peak hour demand and has the potential to sell back energy if there an excess from generation side. The contribution of this paper is three-fold:

- First, this paper attempts to integrate between two of the most noteworthy maritime electrification technologies (cold ironing and microgrid) to enhance sustainable maritime energy replacing conventional operation paradigm. Despite the fact that microgrid is widely use in land based applications, this technology remain scarce for seaport sector.

- Second, this paper presenting optimal design of the seaport microgrid with least-cost option. Comparison between three models is provided.

- Third, response to the three major concern of seaport sector highlighted in the abstract, the optimal framework of seaport microgrid provide an analysis in term of economic feasibility, energy reliability and impact on the emission. This analysis is to highlight how microgrid integration into seaport application capable to cater the above mentioned maritime issue.

The remainder of this paper is structured as follows. In Section 2 reviewed on the optimization and sizing approaches. The methodology used for the design of the seaport microgrid, design parameters, and utilization of optimizer technique is explained in Section 3. Afterwards, the outcome from the proposed design is discussed and analyzed in Section 4. Finally, in Section 5, all significant findings of the paper are summarized.

\section{Sizing}

The optimal design and operation of microgrid has recently been the subject of extensive research. This is supported by an increasing trend of publication and research findings on this area. Ports are critical to the global economy, accounting for big percentage of global merchandise trade by value. As a result, ports are preoccupied with providing labor for processing and handling goods, as well as other port-related services. To- 
day's aggressive development in seaport trading necessitates the best power system option in this sector that capable to operate efficiently and optimally. Here comes the hybrid generation of microgrid system, in which the generation component implements a mix of available clean energy sources with or without grid connection. However, the process to plan and development for this power system at seaport sector involves with a few preliminary actions like long-term planning, research background on the modelling, data collection and forecasting, initial simulation, observation, management and evaluation.

Sizing is an EMS action in determining microgrid's resource coordination, good system configuration and measuring the right capacity of the component to fulfill the load demand. In the meantime, optimization is required to ensure that the system operates at better efficiency, maximizing economic benefit, while minimizing energy consumptions, pollutants, and other related objectives. Sizing and optimization are inextricably linked and complement each other. This is an essential approach for resolving oversizing and under sizing issues to enhance supply reliability. The study of microgrid systems in harbor areas carried out by A. Roy et al. [10] emphasizes the importance of knowing the load demands as well as several evaluation criteria (economic, pollution, reliability, and geographical) in order to determine the sizing of the microgrid.

Generally, optimization-based EMS formulated by identify the objectives and constraints. However, energy demands in seaports are highly dynamic and stochastic, caused by a variety of unpredictable factors such as daily routine, activities handing, and climate change (weather, temperature, and wave). This scenario will cause to the uncertainty in sudden high load and give the impact to the stability of the system [11]. Considering this situation, ensuring enough an availability of power supply is significant to prevent disturbance in maritime power system. P.Xie et al. [12] in their optimization research identify three common objectives and seven constraints at seaport sector, which are simplified in Table 1. From the selected objectives and constraints, an algorithm is developed and simulated to see the optimization result.

Table 1. Frequent objectives and constraints used in port optimization problem

\begin{tabular}{|l|c|}
\hline \multicolumn{1}{|c|}{ Objectives } & Constraints \\
\hline Fuel consumption minimization & Power and energy balance \\
Environmental footprint reduction & Restraints for power quality \\
Economic investment minimization & Restraints of power plants \\
& Restraints of ESS \\
& Environmental constraints \\
& Ship voyage constraints \\
& Constraints for the auxiliary system \\
\hline
\end{tabular}

For this purposed, both of the computational resources and gathered data related to the system is significant in modelling phase. However, there are limitation of real time data especially in port sector. To overcome this challenge, computational simulation is useful method to formulate and evaluate the microgrid power system before implement into the real application. HOMER optimizer is one of the most widely used technique in microgrid optimization and sizing. The system allow a flexible design of power system with equipped weather databased for RESs component. It has an option to design both on grid or standalone microgrid with a mix of components and convenient for financial, energy and emission evaluation. The HOMER optimizer will then search for the optimal size and right quantity for each sub system. Table 2 shows the literature study on the microgrid system using HOMER optimizer in different sector. It simplified their work objectives, design configuration, sector application, sensitivity cases considered, and site location. 
Table 2. Summary of the Microgrid case study using HOMER optimizer

\begin{tabular}{|c|c|c|c|c|c|}
\hline References & Sector & Objectives & Configuration & Sensitivity & $\begin{array}{l}\text { Case study } \\
\text { location }\end{array}$ \\
\hline $\begin{array}{l}{[13]} \\
2018\end{array}$ & $\begin{array}{l}\text { Residential } \\
\text { Cottages }\end{array}$ & $\begin{array}{l}\text {-Multiobjective } \\
\text { (Minimization cost and } \\
\text { emission) } \\
\text {-Nonderivative } \\
\text { optimization }\end{array}$ & $\begin{array}{c}\text { (Standalone } \mathrm{MG}) \\
\text { PV/diesel/ac } \\
\text { load/lead acid } \\
\text { battery/li-ion } \\
\text { battery/converter }\end{array}$ & $\begin{array}{l}\text {-fuel price } \\
\text {-PV generation }\end{array}$ & $\begin{array}{c}\text { Kea, } \\
\text { Greece }\end{array}$ \\
\hline $\begin{array}{l}{[14]} \\
2020\end{array}$ & General & $\begin{array}{l}\text {-Optimize size of the MG } \\
\text { component }\end{array}$ & $\begin{array}{c}\text { (Grid connected) } \\
\text { wind/PV/bat- } \\
\text { tery/load/converter }\end{array}$ & N/A & $\begin{array}{l}\text { Bahir Dar } \\
\text { City, Ethio- } \\
\text { phia }\end{array}$ \\
\hline $\begin{array}{l}{[15]} \\
2016\end{array}$ & $\begin{array}{c}\text { City, } \\
\text { general }\end{array}$ & $\begin{array}{l}\text { - Optimal sizing } \\
\text { - Better management of RES } \\
\text { and storage to fulfill the } \\
\text { loads demand and reduce } \\
\text { the fossil fuel dependency }\end{array}$ & $\begin{array}{c}\text { (Standalone MG) } \\
\text { Wind/solar/micro } \\
\text { turbine/battery/fuel } \\
\text { cell }\end{array}$ & N/A & Nain, Iran \\
\hline $\begin{array}{l}{[16]} \\
2016\end{array}$ & $\begin{array}{c}\text { ATM } \\
\text { machine }\end{array}$ & $\begin{array}{l}\text {-To study feasibility of so- } \\
\text { lar- wind-diesel hybrid } \\
\text { power system with maxim- } \\
\text { ize the use of non-conven- } \\
\text { tional generation system } \\
\text { while minimizing the total } \\
\text { system cost }\end{array}$ & $\begin{array}{l}\text { (Standalone MG) } \\
\text { PV/wind/diesel/gen- } \\
\text { erator/converter/bat- } \\
\text { tery/ac load }\end{array}$ & $\mathrm{N} / \mathrm{A}$ & $\begin{array}{l}\text { Vatar, Kol- } \\
\text { hapur }\end{array}$ \\
\hline $\begin{array}{l}17] \\
2011\end{array}$ & Forest & $\begin{array}{l}\text { - Analyze real time dynamic } \\
\text { data }\end{array}$ & $\begin{array}{l}\text { (Standalone MG) } \\
\text { PV/wind/hydro/gen- } \\
\text { erator/converter/bat- } \\
\text { tery/ac load/fuel cell }\end{array}$ & $\begin{array}{l}\text { - Renewable re- } \\
\text { sources } \\
\text {-Hourly data set } \\
\text { of load } \\
\text {-Lifetime PV ar- } \\
\text { ray }\end{array}$ & $\begin{array}{l}\text { Kondapalli, } \\
\text { India }\end{array}$ \\
\hline $\begin{array}{l}{[18]} \\
2020\end{array}$ & $\begin{array}{l}\text { Rural area } \\
\text { (residential) }\end{array}$ & $\begin{array}{l}\text { - Develop an in-situ con- } \\
\text { forming microgrid, to ex- } \\
\text { plore effect of certain prob- } \\
\text { lems (such as power price, } \\
\text { grid failure frequency, and } \\
\text { grid mean repair time) and } \\
\text { its effect to cost (total oper- } \\
\text { ating cost, total capital cost, } \\
\text { net present cost), electricity } \\
\text { production, and unmet load }\end{array}$ & $\begin{array}{l}\text { (grid connected) } \\
\text { PV/battery }\end{array}$ & $\begin{array}{l}\text { - Grid failure fre- } \\
\text { quency } \\
\text {-Grid mean re- } \\
\text { pair time }\end{array}$ & $\begin{array}{l}\text { South Af- } \\
\text { rica }\end{array}$ \\
\hline $\begin{array}{l}{[19]} \\
2020\end{array}$ & $\begin{array}{l}\text { Agricultural } \\
\text { Load } \\
\text { (residential } \\
\text { and water } \\
\text { pumping) }\end{array}$ & $\begin{array}{l}\text { - To investigates the feasi- } \\
\text { bility of the hybrid system }\end{array}$ & $\begin{array}{c}\text { (Standalone MG) } \\
\text { grid/battery/PV/die- } \\
\text { sel generator/ac } \\
\text { load/water pumping } \\
\text { load/converter }\end{array}$ & $\begin{array}{l}\text { Variations in PV } \\
\text { cost, diesel fuel } \\
\text { price, and maxi- } \\
\text { mum annual ca- } \\
\text { pacity shortages } \\
\text { (MACS) }\end{array}$ & $\begin{array}{l}\text { Ein Al- } \\
\text { baida, Pal- } \\
\text { estine }\end{array}$ \\
\hline $\begin{array}{l}{[20]} \\
2017\end{array}$ & $\begin{array}{c}\text { Remote } \\
\text { area }\end{array}$ & $\begin{array}{l}\text {-To study two sizing meth- } \\
\text { ods for a stand-alone hybrid } \\
\text { generation using basic } \\
\text { equations and Simulink De- } \\
\text { sign Optimization (SDO) } \\
\text { and HOMER optimizer }\end{array}$ & $\begin{array}{c}\text { (Standalone MG) } \\
\text { Hydroki- } \\
\text { netic/PV/diesel gen- } \\
\text { erator/battery/ac } \\
\text { load }\end{array}$ & $\mathrm{N} / \mathrm{A}$ & $\begin{array}{l}\text { Isla Santay } \\
\text { (Guayaquil) }\end{array}$ \\
\hline
\end{tabular}




\begin{tabular}{|c|c|c|c|c|c|}
\hline$[21]$ & Seaport & - Energy planning & $\begin{array}{c}\text { (grid connected) } \\
\text { PV/wind/battery/AC } \\
\text { load/converter }\end{array}$ & $\begin{array}{c}\text { Copenha- } \\
\text { gen, Den- } \\
\text { mark }\end{array}$ \\
\hline$[22]$ & $\begin{array}{c}\text { Domestic } \\
\text { load }\end{array}$ & -Minimizing the cost system & $\begin{array}{c}\text { Bio- } \\
\text { mass/PV/wind/bat- } \\
\text { tery/dual con- } \\
\text { verter/electrical } \\
\text { load/dumb load }\end{array}$ & N/A & $\begin{array}{c}\text { Yanbu, } \\
\text { baudi Ara- } \\
\end{array}$ \\
& & & & \\
& & \\
\end{tabular}

Despite the gradual increase number of research works concerning microgrid power system, there is limited exploitation of the overall sizing for the microgrid, particularly at seaport sector. This inadequate exploration motivated this research work to enrich current innovation power system to the seaport. Therefore, this paper develops a simulationbased method to determine the best configuration and overall sizing for hybrid generation in seaport microgrid by utilizing HOMER optimizer. Subtopic 3.0 below explained the flow of the methodology involved from designing microgrid structure, parameter used and optimizer simulation.

\section{Optimization framework}

\subsection{Structure of the proposed seaport microgrid}

The proposed design of the seaport microgrid is developed by considering RESs and ship demand during berthing. The Port of Aalborg has been selected as a case study, which is located approximately at latitude $57^{\circ} 3.0^{\prime} \mathrm{N}$ and longitude $10^{\circ} 3.2^{\prime} \mathrm{E}$, where sources of energy mainly come from the utility grid, diesel generators, WTs, and PV systems. The Port of Aalborg handles a wide variety of goods and services such as container, cargo, railway, road, cruise, ships and custom warehouse. However, in the modeling process, only the required power of ships during berthing is considered as the load as it imposes a high-energy demand on the port.

This paper aims to find the optimal seaport microgrid configuration and the optimal size of each component with the goal of cost minimization. Besides, identifying the lowest Net Present Cost (NPC) for the candidate architecture is a vital step in the seaport microgrid planning process to enjoy the benefit from the system. For instance, payback period is worth for the investment by the stakeholder and the energy consumption would then be free during project lifetime. From the environmental perspective, RESs component in microgrid provide the solution to the resources depletion issue and offer green port landscape because it is environmental friendly. Figure 2 illustrates the overview of the seaport microgrid configuration. The schematic design shows the proposed system in this paper connected with the main grid and consist of PV, wind and diesel generator as a sources component, lithium- ion as a storage solution, converter between AC/DC busbar and ships as an electrical load. 

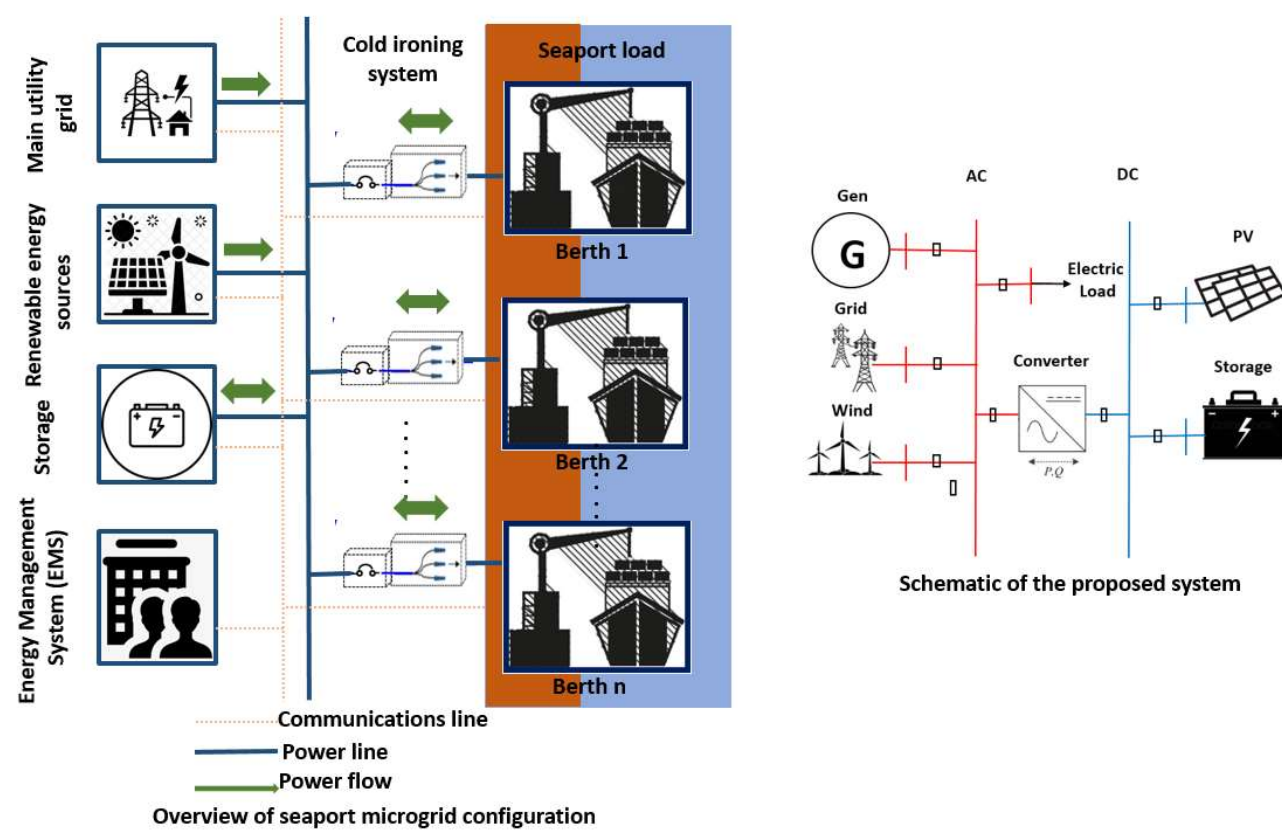

Schematic of the proposed system

Figure 2. Overview and schematic diagram of the proposed system.

\subsection{Load profile}

In the Port of Aalborg, ships are among big energy consumers. Conventionally, when a ship is at berth, the auxiliary engines are turned on to support some basic functions and auxiliary loads in the ship that need electrical power. Diesel generator burning from the ship has negative impact to the environment. Nowadays, with the green maritime goals of the shipping industry to reduce ship emission, cold ironing that also known as the onshore power supply (OPS) comes to the scene offering a promising solution [23]. This technology allows the ship to shut down its engines while berthed and plugs into a power source at the shore side [7]. In this way, the ship has the power supply to satisfy the onboard energy demand such as emergency equipment, cooling, heating, lighting, and refrigeration without having to burn diesel fuels.

The load profile of ships during berthing varies according to three factors including time of berthing, the number of ship berthing per time, and the required power by the particular ship. There are different times of berthing for each ship and various numbers of ship berthing at the port from time to time. N. Ahamad et al. [24] summarize the average time of berthing and typical power requirement for different types of vessels as listed in Table 3.

Table 3. Average berthing time and average power requirement for various types of vessels

\begin{tabular}{|c|c|c|}
\hline Type of ships & $\begin{array}{c}\text { Average time berthing } \\
\text { (hrs) }\end{array}$ & Average Power \\
\hline $\begin{array}{c}\text { Chemical and other } \\
\text { tankers }\end{array}$ & $24-28$ & $5 \mathrm{MW}-6 \mathrm{MW}$ \\
\hline Bulk carrier & 52 & N/A \\
\hline Container & 21 & $1 \mathrm{MW}-4 \mathrm{MW}$ \\
\hline General cargo & 25 & $300 \mathrm{~kW}-6 \mathrm{MW}$ \\
\hline Ferries and RoRo & 24 & $700 \mathrm{~kW}$ \\
\hline Cruise & 28 & $7 \mathrm{MW}$ \\
\hline
\end{tabular}


The load profile used in the simulation in this study is shown in Figure 3. Peak hours are observed to be between 6 a.m. to 7 p.m. and the load slowly reduces afterward. According to this load profile, the average energy consumption is $23977 \mathrm{kWh} /$ day which indicates that the average power per hour is $999.07 \mathrm{~kW}$ with a peak value of $2734.2 \mathrm{~kW}$. Even though the power consumed by ships at the port depends on a few factors mentioned above during different periods and seasons of the year, it can be generally assumed that the peak load occurs during the afternoon as there are fewer ships berthing between 8.00 p.m. until 5.00 a.m. In order to prevent from underrating the peak load, the data recording was set to random variabilities of $10 \%$ the day to day and $16 \%$ time step in the simulation.

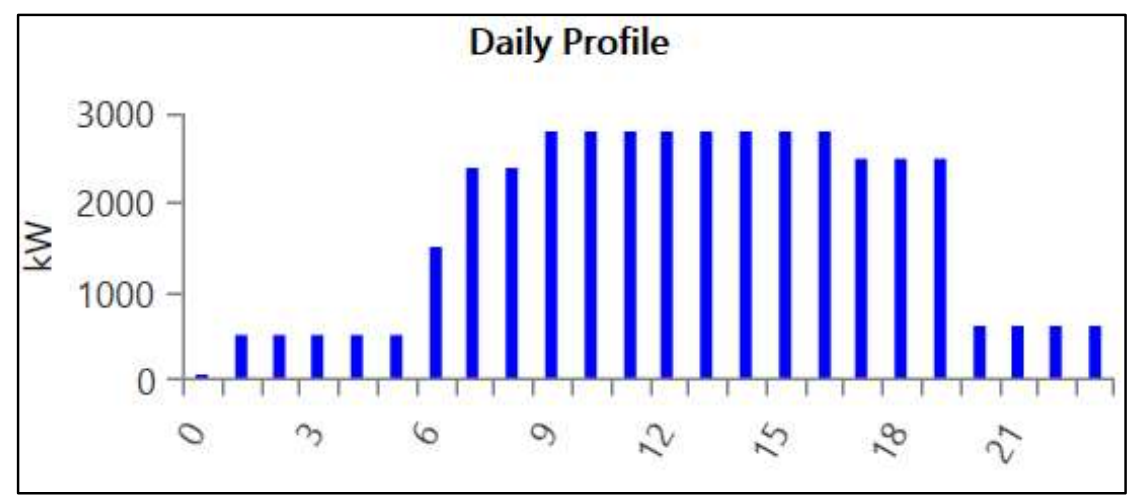

Figure 3. Hourly load profile in one day.

\subsection{Meteorological data}

\subsubsection{Solar radiation and temperature}

All the meteorological data used in this simulation like solar GHI data, wind resources and temperature resources is from NASA Prediction of Worldwide Energy Resources (POWER) database. The extracted data are related to the site location specified by the port coordination so that the approximation of the WT and PV output power produced in the simulation will be more accurate. The bar chart in Figure 4 shows that the highest daily radiation readings occur in May, June, and August. It is because Denmark is in the midst of its summer season at the time. Most of the days are sunny with a longer daylight period. Meanwhile, in the other seasons, sun irradiation is low because it is cloudy and rainy most of the days. The irradiance range from $0.35 \mathrm{kWh} / \mathrm{m}^{2} /$ day to $6.06 \mathrm{kWh} / \mathrm{m}^{2} /$ day with an annual average of $3.02 \mathrm{kWh} / \mathrm{m}^{2} /$ day. The orange line indicates that the maximum clearness index is 0.55 and the minimum clearness index is 0.338 .

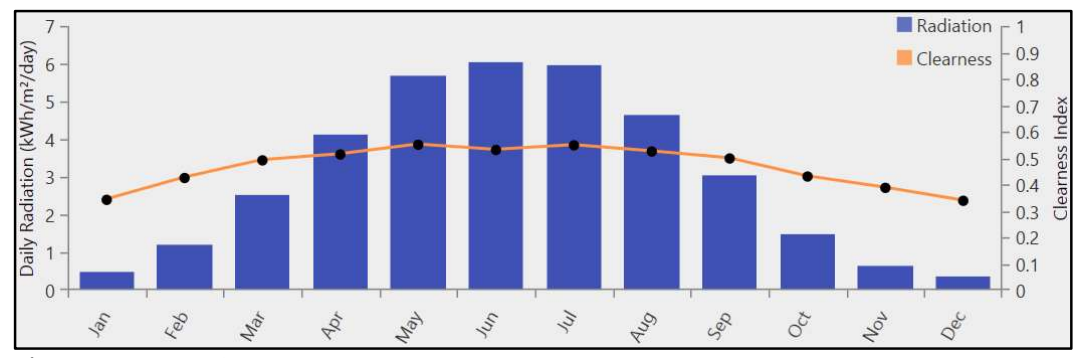

Figure 4. Solar GHI resources in one year.

Bar chart in Figure 5 displays the readings of the monthly average air temperature for this location. Range of temperature figure is between $0.94^{\circ} \mathrm{C}$ and $16.66^{\circ} \mathrm{C}$ with an annual average of $8.36^{\circ} \mathrm{C}$. The warmest months are June, July, August, and September, with 
an average temperature of $14.11^{\circ} \mathrm{C}, 16.66^{\circ} \mathrm{C}, 16.66^{\circ} \mathrm{C}$, and $13.44^{\circ} \mathrm{C}$, respectively. The temperature begins to fall sharply at the end of autumn and reaches its lowest point in February $\left(0.94{ }^{\circ} \mathrm{C}\right)$.

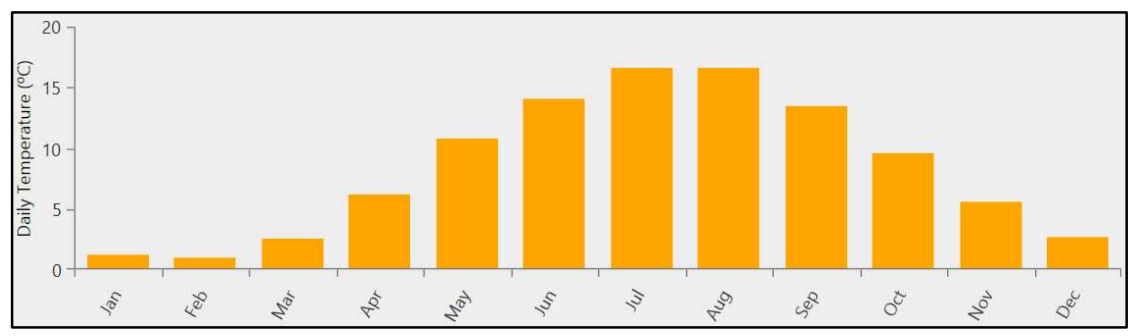

Figure 5. Average monthly temperature data of the target site in one year.

A. Haidar et al. [25] in their research work highlighted that the generated power from PV modules is directly related with a few parameters such as solar irradiance, temperature, the capacity of PV array, and its derating factor. This can be explained by equation (1) that is used to determine the optimal capacity of the solar PV at time $t$.

$$
P_{p v}(t)=P_{p v}^{r a}(t) \times f_{p v} \times\left(\frac{I}{I_{e}}\right) \times\left[1+T_{c}\left(C_{T}-C_{T c}\right)\right]
$$

Where $P_{p v}^{r a}(t)$ is PV array rated capacity $(\mathrm{kW}), f_{p v}$ is derating factor, $I$ is irradiance incident on PV plate $\left(\mathrm{kW} / \mathrm{m}^{2}\right), I_{e}$ is irradiance at the standard test condition $\left(\mathrm{kW} / \mathrm{m}^{2}\right), T_{c}$ is temperature coefficient, $C_{T}$ is cell temperature, and $C_{T c}$ is cell temperature at the standard test condition.

\subsubsection{Wind resources}

The power generation of WTs relies heavily on weather conditions such as wind speed and wind direction [26]. A common linear mathematical model for wind energy generation estimation used to find the dynamical power curve of WTs output power is defined in equation (2) as follows [27]:

$$
P_{w}(v)=\left\{\begin{array}{lc}
0, & 0 \leq v \geq v_{\text {in }} \\
P_{r}, \frac{v-v_{\text {in }}}{v_{r}-v_{\text {in }}}, & v_{\text {in }} \leq v \geq v_{r} \leq v \geq v_{\text {out }} \\
P_{r}, & v \geq v_{\text {out }}
\end{array}\right.
$$

Where $P_{w}(v)$ is the power output of wind energy at wind speed $\mathrm{v}, P_{r}$ is the WT rated power, $v_{r}$ is the rated wind speed, $v_{i n}$ is cut-in wind speed, and $v_{o u t}$ is cut-out wind speed.

Figure 6 illustrates the monthly average wind speed at the height of $50 \mathrm{~m}$ above the surface of the earth over one year period. The annual average wind speed is $8.17(\mathrm{~m} / \mathrm{s})$, with the highest being $9.62(\mathrm{~m} / \mathrm{s})$ in January and the lowest being $6.81(\mathrm{~m} / \mathrm{s})$ in July. Due to the wind speed variation with height, it is plotted on a logarithmic scale. As can be seen in this figure, the wind speed increases with height because there are less obstacles and turbulence along the increasing height and wind. 


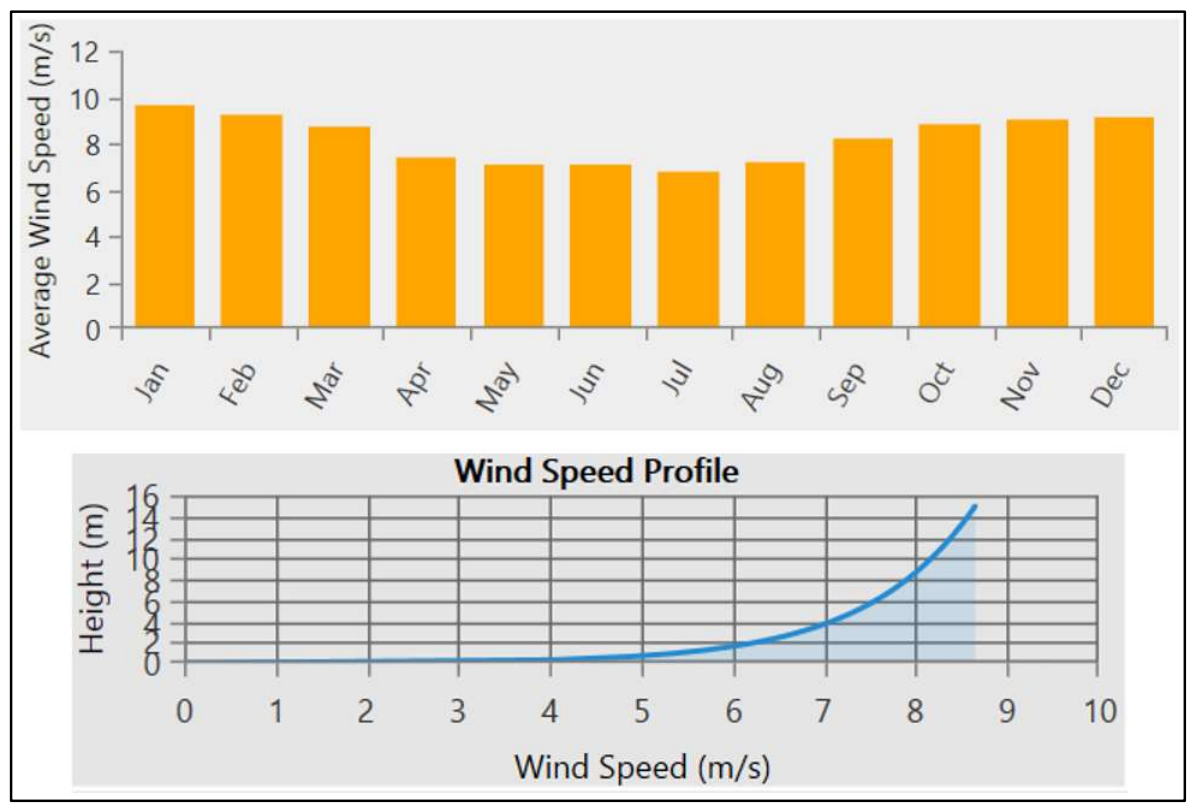

Figure 6. Wind speed profile of the target site in one year.

\subsection{HOMER optimizer}

\subsubsection{Schematic design and component parameters of the proposed seaport microgrid}

Hybrid Optimization of Multiple Energy Resources (HOMER) is a simulation-based software used to optimize any integrated system by finding the right size of the equipment and the best possible system configuration while minimizing the Net Present Cost (NPC). It stimulates the designed electric power system hour by hour for a year in the specific region considering the available energy resources present at the location. For each time step, HOMER searches for many different configurations that satisfy the technical constraints at the lowest life cycle cost to meet the electrical load. Users can simulate their proposed power system and HOMER delivers the optimal candidate design.

Furthermore, it has the ability to perform sensitivity analysis to examine the impact of uncontrollable variables to see how they may affect the designed system costs. These variables include the price of fuel, which is always volatile, the price of components, lifetime data, efficiency, and other parameters that is unsure how they will change in the future. Sensitivity analysis is critical for understanding the design's robustness. It enables users to be aware of how changing the input parameters affects the system architecture and cost.

HOMER is a designer-friendly software and can perform system design optimization based on the system configuration and various settings provided by the designer. Based on the proposed system in Subsection 3.1, the required components are added to HOMER software. The schematic diagram of the system is shown in Figure 2. All the technical parameters and economic features employed are either from HOMER database or real data from commercial datasheets. Replacement cost is assumed to be $5 \%-10 \%$ less than the capital cost.

\subsubsection{Optimization and algorithm}

HOMER has two optimization algorithms, which are; 1) Derivative-free algorithm and 2) Search algorithm. During the design process, the user may encounter a problem with determining the appropriate sizing or capacity for components that are compatible with the system. For the derivative-free algorithm, HOMER will automatically choose the 
appropriate sizing aiming for the least system cost. On the other hand, the search algorithm will simulate every possible system configuration by the quantity defined in the search space. The input value of the 'search space' varies depending on the peak load measurement. The selected size has a portion that is at the upper or lower end of the search space. It then specifies the best realizable system configuration capable of meeting the electric demand and finalized it into a few categories. Table 4 shows the type of the optimization option used by each of the component in this simulation.

Table 4. Optimization option used to determine the size for each component in the proposed design

\begin{tabular}{|c|c|c|}
\hline Component & HOMER optimizer & Search space \\
\hline Diesel generator & $\checkmark$ & - \\
\hline Wind turbine & - & $5,10,15,20,25$ \\
\hline PV & - & $250,500,1000,1500,2000,2500,3000,3500$ \\
\hline Battery & $\checkmark$ & $0 \sim 2880$ \\
\hline Converter & - & \\
\hline
\end{tabular}

Other algorithms that are used in HOMER are Net Present Cost (NPC), Levelized Cost of Energy (COE), operating cost and renewable fraction. The NPC or known as lifecycle cost of a component is the present value of all the costs of establishing and operating every component in a system over the project lifetime, minus the present value of all the revenues that it earned over the project lifetime as shown in (3).

$$
C_{N P C}=C_{P}-C_{R}
$$

Where $C_{P}$ is present value of all costs over the project lifetime and $C_{R}$ is present value of all revenues earned over the project lifetime.

Costs calculated in the algorithm embrace capital costs, replacement costs, O\&M costs, fuel costs, emissions penalties, and the costs of buying power from the grid. Meanwhile, salvage value and grid sales revenue are included in the revenue. Overall, NPC is the HOMER's main economic output which is used to rank all system configurations in the optimization results and is the basis from which the total annualized cost and the levelized cost of energy (COE) are calculated as follows;

$$
C O E=\frac{C_{a n n, t o t}-C_{\text {boiler }} H_{\text {served }}}{E_{\text {served }}}
$$

Where $C_{\text {ann,tot }}$ is total annualized cost of the system [\$/yr], $C_{\text {boiler }}$ is boiler marginal cost $[\$ / \mathrm{kWh}], H_{\text {served }}$ is total thermal load served $[\mathrm{kWh} / \mathrm{yr}]$, and $E_{\text {served }}$ is total electrical load served $[\mathrm{kWh} / \mathrm{yr}]$. Meanwhile, in order to calculate the operating cost for the system, equation (5) is utilized.

$$
C_{\text {operating }}=C_{\text {ann,tot }}-C_{\text {ann,capital }}
$$

Where $C_{a n n, t o t}$ is the total annualized cost [\$/yr] and $C_{\text {ann,capital }}$ is the total annualized capital cost $[\$ / y r]$. To have an efficient system, it is highly recommended to include the RESs in the architecture. The renewable fraction used in HOMER refers to the percentage of the energy supplied to the loads that come from RESs. It can be calculated using the following equation;

$$
f_{\text {ren }}=1-\frac{E_{\text {nonren }}-H_{\text {nonren }}}{E_{\text {served }}-H_{\text {served }}}
$$

Where $E_{\text {nonren }}$ is nonrenewable electrical production $[\mathrm{kWh} / \mathrm{yr}], H_{\text {nonren }}$ is nonrenewable thermal production $[\mathrm{kWh} / \mathrm{yr}], E_{\text {served }}$ is total electrical load served [kWh/yr], and $H_{\text {served }}$ is total thermal load served [kWh/yr].

\subsubsection{Mathematical formulation of the Objective Function and Constraint}

The objective function of the optimization problem is to minimize the operation cost. It is define by: 
Objective function:

$\min \left(C_{\text {total }}\right)=\sum P_{\text {grid }} C_{\text {grid }}+P_{g e n} C_{g e n}+P_{w t} C_{w t}+P_{p v} C_{p v}+P_{b a t} C_{b a t}+P_{c o n} C_{c o n}$

Where cost of the each element considering the cost of capital, operation and maintainance, replacement and fuel as in equation below:

$C_{\text {element }}=\sum C_{\text {capital }}+C_{\text {o\&M }}+C_{\text {replacement }}+C_{\text {fuel }}$

The objective function is subject to the power balance between generation and demand and also percentage of renewable energy.

Constraints:

$P_{\text {grid }}+P_{\text {gen }}+P_{w t}+P_{p v}+P_{\text {bat }}+P_{\text {con }} \geq P_{\text {load }}$

$P_{w t}+P_{p v} \geq 85.2 \%$

\subsection{Energy Management System (EMS) in the design phase}

The complexity of multiple power resources coordination, varying electrical loads, fluctuation in economical variables, and assessing the environmental impact require the use of an EMS in both design and planning phases. EMS focuses on the use and preparation of energy sources over a specific time frame and is often combined with future forecasting and projection systems [12]. It is strongly related with both of the energy efficiency as well as cost saving. However, different functionalities and requirements can be defined for the EMS depending on the situation and the microgrid application.

In this design, three key concerns that are taken into account are minimization of fuel consumption, environmental impact, and economic investment. The big question is what kind of system configuration and sizing specification should be considered. In order to satisfy this, RESs and storage elements are included in the design process. PVs and WTs in the schematic diagram represent the RESs meanwhile battery represents the storage component. The use of RESs will help to sustain the energy supply and its environmentally friendly characteristic will protect the environment from harmful emissions. Since the sources are from nature (sun and wind), RESs also provide the microgrids with a costeffective power generation solution. Furthermore, any excess energy generated by RESs can be sell back to the grid bringing further economic benefits.

Utilization of the battery as an ESS is beneficial for both having an energy backup during critical periods (energy shortage and peak hours) and storing the excess energy when energy generation is abundant. RESs like PV and WT have some limitations for power production. PVs are only able to generate power during the day, depending on both solar radiation and temperature. PV power output is also reduced on cloudy and rainy days. The same situation exists for the WTs, where wind speed varies depending on the site location and seasonal wind patterns. ESS is a vital component to store excess energy from both solar and wind sources when they have high power generation and supply the loads during periods of low energy availability, such as peak hours and power shortage intervals. Figure 7 illustrates how EMS plays part in the seaport microgrid system. 


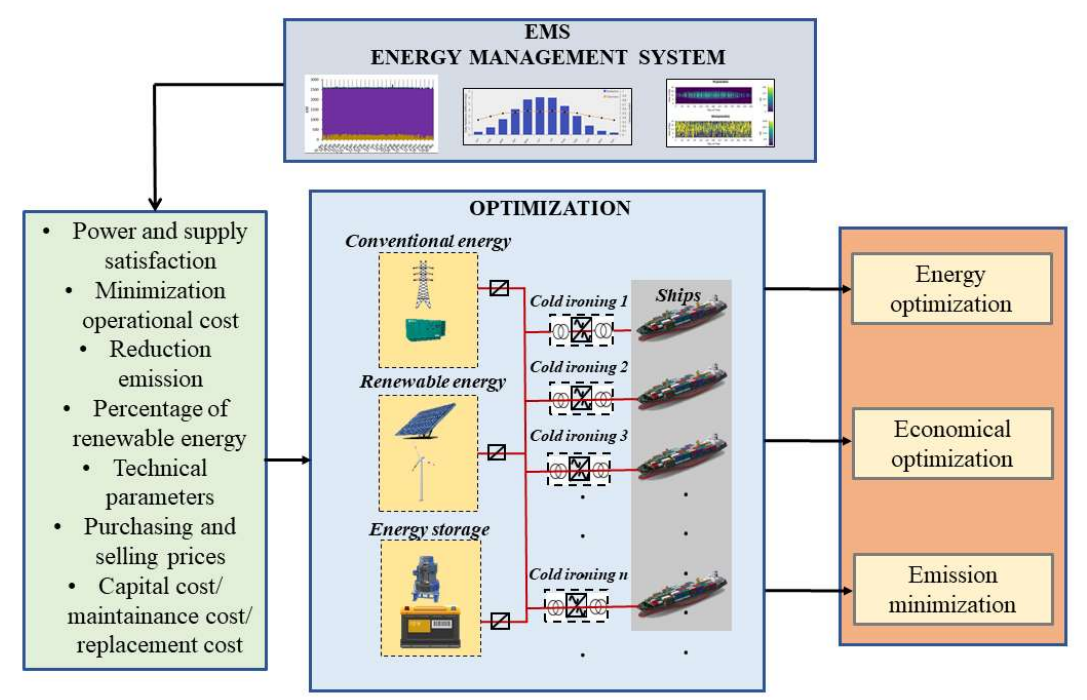

Figure 7. Energy Management System (EMS) in seaport microgrid.

\section{Optimal sizing of seaport microgrid}

In this section, three different models, namely Model1, Model2, and Model3 are investigated for the optimal hybrid seaport microgrid where; Model1 is the optimal result from the proposed system, Model2 is the best system recommended by HOMER meanwhile Model3 is a conventional system without battery and RESs. Table 5 shows the detailed comparison between optimization result for Model1, Model2 and Model3. All systems are resultant from the simulation during 25 years lifetime of the project.

Optimization results from the proposed design indicates that the best architecture for the target hybrid seaport microgrid is the grid/pv/wind/converter configuration (Model2) with the optimally-sized components featuring the lowest NPC. The best system is selected based on the lowest value of NPC, which is $\$ 4,718,247$ for Model2, $\$ 5,920,870$ for Model1, and $\$ 26,981,960$ for Model3. The significant change that can be seen from Model2 compared to the proposed system is in relation to its components where it has no diesel generator and battery.

Conventionally, without microgrid technology, the seaport sector relied only on the supply of electricity from the main utility grid and diesel generator to run their daily operation. According to Table 5, this architecture (Model3) has the lowest initial capital, which is $\$ 1.4 \mathrm{M}$, as the system does not need to invest in any other component like RESs installation, ESSs, and power converters. Unfortunately, the system has highest NPC value with $\$ 26 \mathrm{M}$. The conventional system is highly dependent on the raw material of the power resources like coal and diesel that produce very high greenhouse gas emissions in the environment. In term of emission analysis, this system produce $5531162 \mathrm{~kg} / \mathrm{yr}$ of $\mathrm{CO}_{2}$, $23980 \mathrm{~kg} / \mathrm{yr}$ of $\mathrm{SO}_{2}$ and $11727 \mathrm{~kg} / \mathrm{yr}$ of NOx. Meanwhile, the hybrid microgrid system with optimal sizing in Model 2 offers a big amount of emission reduction with a total reduction of $82.51 \%$ in $\mathrm{CO} 2,74.98 \%$ in $\mathrm{SO}_{2}$, and $74.98 \%$ in NOx compared to the conventional model. Besides producing hazardous pollutants, the conventional system also faces the problem of fossil resource depletion [28][29]. That explains, the reason why microgrid technology utilization important for seaport sector. The advantage of hybrid RESs and ESSs from microgrid will increase energy efficiency, provide sustainable energy while offering a longterm cost-effective solution for port electrification and decarbonization atmosphere. 
Table 5. Optimization result

\begin{tabular}{|c|c|c|c|c|}
\hline \multicolumn{2}{|r|}{ Parameter } & \multirow{2}{*}{$\begin{array}{c}\text { Proposed system } \\
\text { (model 1) }\end{array}$} & \multirow{2}{*}{$\begin{array}{c}\text { Optimal } \\
\text { System } \\
\text { (model 2) } \\
\text { Grid/PV/Wind/Co } \\
\text { nverter }\end{array}$} & \multirow{2}{*}{$\begin{array}{c}\text { Conventional } \\
\text { system } \\
\text { (model 3) }\end{array}$} \\
\hline \multirow{9}{*}{ 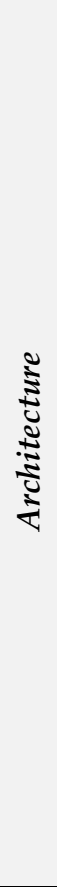 } & Configuration & & & \\
\hline & Difference & - & $\begin{array}{l}\text {-no battery } \\
\text {-no diesel } \\
\text { generator }\end{array}$ & $\begin{array}{l}\text {-no RESs } \\
\text {-no battery }\end{array}$ \\
\hline & SM500(kW) & 250 & 250 & - \\
\hline & $\begin{array}{c}\text { SM500- } \\
\text { MPPT }(k W)\end{array}$ & 500 & 500 & - \\
\hline & Norv22 & 25 & 25 & - \\
\hline & Gen $(k W)$ & 3100 & - & 2800 \\
\hline & 100LI & 1 & - & - \\
\hline & Grid(kW) & 999999 & 999999 & 999999 \\
\hline & ABB-PSC(kW) & 90 & 90 & - \\
\hline \multirow{4}{*}{$\tilde{s}$} & NPC (\$) & 5920870 & 4718247 & 26981960 \\
\hline & COE (\$) & 0.0309 & 0.0246 & 0.2385 \\
\hline & $\begin{array}{c}\text { Operating cost } \\
(\$ / y r)\end{array}$ & -42392 & -14748 & 1978877 \\
\hline & Initial capital $(\$)$ & $6.47 \mathrm{M}$ & $4.91 \mathrm{M}$ & $1.4 \mathrm{M}$ \\
\hline \multirow[b]{2}{*}{$\frac{5}{\frac{1}{0}}$} & RES frac (\%) & 85.2 & 85.2 & - \\
\hline & Total fuel (L/yr) & 0 & 0 & 0 \\
\hline \multirow{2}{*}{$\sum_{\text {क }}^{8}$} & Capital cost $(\$)$ & 300000 & 300000 & - \\
\hline & $\begin{array}{c}\text { Production } \\
(\mathrm{kWh} / \mathrm{yr})\end{array}$ & 315315 & 315315 & - \\
\hline \multirow{3}{*}{$\frac{\mathfrak{z}^{2}}{2}$} & Capital cost (\$) & 4500000 & 4500000 & - \\
\hline & $\begin{array}{c}\text { Production } \\
(\mathrm{kWh} / \mathrm{yr})\end{array}$ & 12435239 & 12435239 & - \\
\hline & O\&M & 125000 & 125000 & - \\
\hline \multirow[b]{2}{*}{ స్తి } & Autonomy (hr) & 0.0801 & - & - \\
\hline & $\begin{array}{c}\text { Annual } \\
\text { throughput } \\
(\mathrm{kWh} / \mathrm{yr})\end{array}$ & 320 & - & - \\
\hline
\end{tabular}




\begin{tabular}{|c|c|c|c|c|}
\hline & $\begin{array}{c}\text { Nominal capacity } \\
(\mathrm{kWh})\end{array}$ & 100 & - & - \\
\hline & $\begin{array}{l}\text { Usable Nominal } \\
\text { Capacity (kWh) }\end{array}$ & 80 & - & - \\
\hline \multirow{2}{*}{$\begin{array}{l}u \\
\text { की } \\
\frac{1}{1} \\
\frac{\infty}{10}\end{array}$} & $\begin{array}{l}\text { Rectifier Mean } \\
\text { Output }(\mathrm{kW})\end{array}$ & 0.0385 & 0 & - \\
\hline & $\begin{array}{c}\text { Inverter Mean } \\
\text { Output }(\mathrm{kW})\end{array}$ & 24.4 & 24.3 & - \\
\hline \multirow{2}{*}{ : } & $\begin{array}{c}\text { Energy } \\
\text { purchased (kWh) }\end{array}$ & 2189430 & 2189312 & 8751839 \\
\hline & $\begin{array}{c}\text { Energy sold } \\
(\mathrm{kWh})\end{array}$ & 6085820 & 6085762 & - \\
\hline \multirow{3}{*}{ 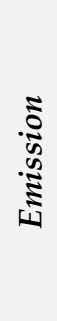 } & $\begin{array}{c}\text { Carbon Dioxides } \\
(\mathrm{kg} / \mathrm{yr})\end{array}$ & 1383720 & 1383645 & 5531162 \\
\hline & $\begin{array}{c}\text { Sulfur Dioxide } \\
(\mathrm{kg} / \mathrm{yr})\end{array}$ & 5999 & 5999 & 23980 \\
\hline & $\begin{array}{c}\text { Nitrogen } \\
\text { Oxides(kg/yr) }\end{array}$ & 2934 & 2934 & 11727 \\
\hline
\end{tabular}

According to the simulation results, the best architecture for the seaport microgrid in this project which is Model 2 consists of a $250 \mathrm{~kW}-\mathrm{PV}, 25100 \mathrm{~kW}-\mathrm{WT}$, and a $90 \mathrm{~kW}$-converter with a connection to the main grid. This microgrid requires $40665 \mathrm{kWh} /$ day and has a peak power demand of $2734 \mathrm{~kW}$. The amount of excess electricity is $93388 \mathrm{kWh} / \mathrm{yr}$. Figure 8 shows the graph of energy production from both utility grid and RESs that serve the electrical load. According to this figure, a big share of the produced power is related to RESs where $12435239 \mathrm{kWh} /$ year is produced by the WTs, $315315 \mathrm{kWh}$ /year from PV, and only $2189312 \mathrm{kWh}$ energy is purchased from the main grid. This indicates a RES fraction of $85.3 \%$ while $14.7 \%$ of the power is from the main grid. The total energy production from PV, WT, and the main grid is equal to $14939866 \mathrm{kWh}$, from which $59 \%$ is used to supply the required power of the electrical loads (ships) and the rest, $41 \%$ of excess energy, is sold back to the main grid. The amount of sold energy is $6085762 \mathrm{kWh}$, a much higher than the energy purchased from the grid. In terms of emission, $1383645 \mathrm{~kg} / \mathrm{yr}$ of CO2, $5999 \mathrm{~kg} / \mathrm{yr}$ of $\mathrm{SO}_{2}$, and $2934 \mathrm{~kg} / \mathrm{yr}$ of NOx are produced. The opportunity to gain extra money from selling back the energy to the main grid and reduction of emission compared to the conventional model is due to the deployment of RESs in the microgrid. Elimination of diesel generation and ESS in this model compared to the proposed system is because power generation from RESs is more than enough to supply the current load. Energy from diesel generator and battery is not necessary in this case. Likewise, the additional component of battery will increase the capital cost. 


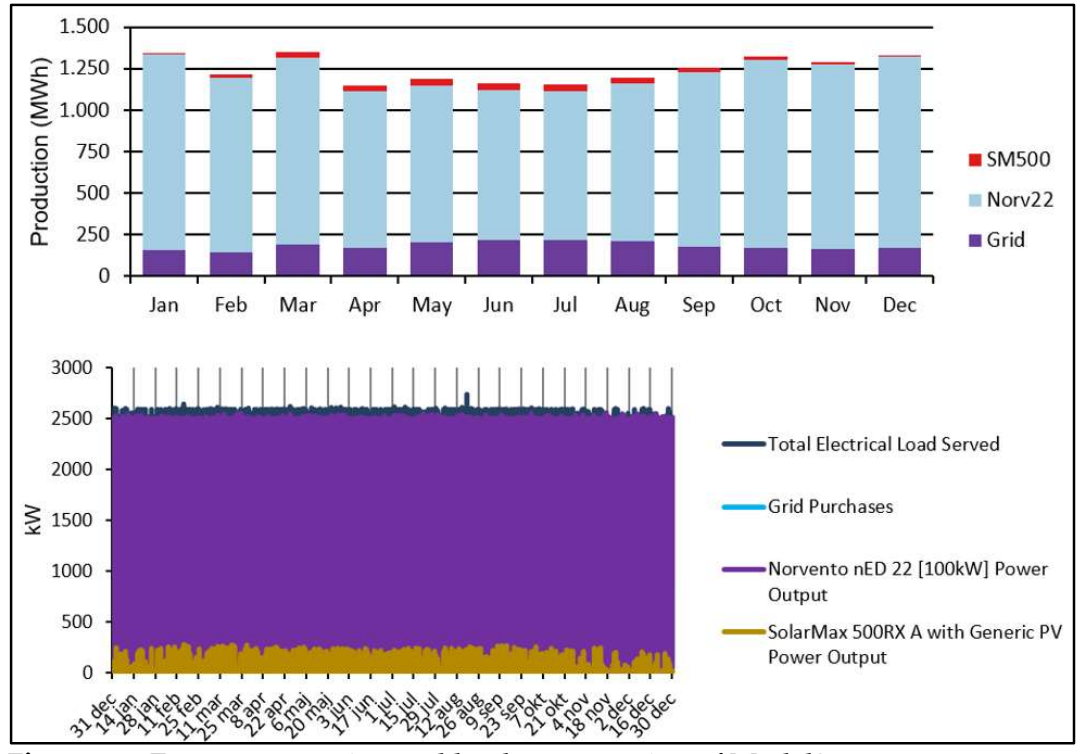

Figure 8. Energy generation and load consumption of Model2.

Figure 9 shows both the PV and WTs power generation in Model2 for a one-year duration. From the $85.3 \%$ of renewable energy fraction, $2.11 \%$ is from solar PV SM500 while the rest $83.2 \%$ comes from Norv22 WT. The amount of energy produced by RESs and its reliability depend on the site location and the available natural resources. In this case study, Denmark as a seasonal country will experience high irradiation during the warm months (May, Jun, and July) due to the sunny climate and long hours of daylight. In those particular months, the output from the PV system will be higher compared to the power produced in other months with a high chance of having cloudy and rainy days. This limitation explains the reason for the small contribution of the PV system.

In the meantime, Denmark is a rich country in terms of wind resources as this country has relatively average wind speeds of 4.9-5.6 m/s measured at a height of 10 meters. Denmark has vast offshore and onshore wind resources, as well as large swaths of sea territory with shallow water depths of 5-15 meters, ideal for sitting WTs. Higher wind speeds, in the range of $7.08-9.62 \mathrm{~m} / \mathrm{s}$ at $50 \mathrm{~m}$ height, are also available at these locations. There have been no big issues from wind variability.

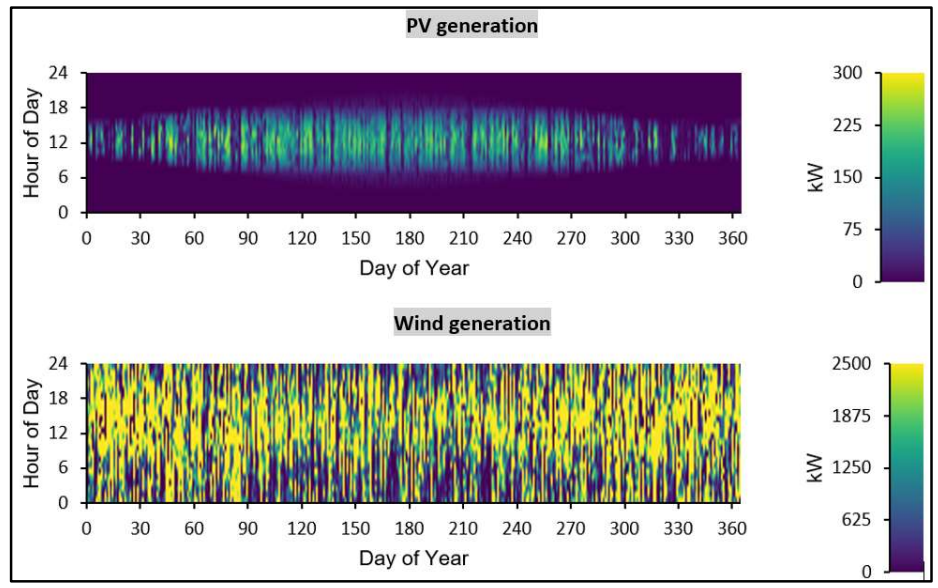

Figure 9. PV and Wind generation of model 2. 


\section{Conclusions}

This paper's contribution is to provide the best architecture configuration for a seaport microgrid with an appropriate sizing capacity in its components while considering cost minimization. A thorough discussion of a conventional seaport design (grid/generator) and two other optimization hybrid design based on microgrid technology was provided with comparing them in terms of cost, energy production, and emissions. The main conclusions that have been drawn from this research include:

- A grid/PV/wind/converter configuration of a 250kW-PV, $25100 \mathrm{~kW}-W T s$, and a $90 \mathrm{~kW}$ converter with the lowest NPC of $\$ 4718247$ is the best seaport microgrid model to serve the given ship's load at the target port.

- In comparison to the originally proposed system, the best model from simulation considers removing the battery and diesel generator components because the energy from the battery and generator is not required. PV and wind power generation generate massive amounts of energy, more than enough to supply the entire load; $59 \%$ of that is used to power the electrical load, with the remaining $41 \%$ of excessive energy is sold back to the grid. Additional of the ESS also will increase the overall capital cost.

- In terms of emissions aspect, the optimal design offers a significant reduction in $\mathrm{CO} 2, \mathrm{SO} 2$, and $\mathrm{NOx}$ emissions, with a total reduction of $82.51 \%$ in $\mathrm{CO} 2,74.98 \%$ in $\mathrm{SO} 2$, and $74.98 \%$ in $\mathrm{NOx}$.

- According to the findings of this study, emission reduction and cost-effectiveness offered by microgrid technology prove that hybrid microgrids with RESs provide a promising solution for electrification of the future seaports following green maritime goals and the sustainable energy system paradigm. It is also a cost-effective way to help the environment's long-term viability.

During the modeling process, by considering EMS, it is critical to determine the proper system sizing and the right component configuration. In the proposed optimal configuration, more than $80 \%$ of electricity is generated from RESs, while only $14.7 \%$ of energy is purchased from the main grid. This system also manages to sell a considerable amount of energy back to the main grid. It solves the shortage energy problem and ensures that the seaport can operate smoothly.

Acknowledgments: This research work was supported by a Villum Investigator grant (no. 25920) from The Villum Fonden (www.crom.et.aau.dk), University Malaysia Perlis (UniMAP) and Ministry of Education Malaysia. The Deanship of Scientific Research (DSR) at King Abdulaziz University, Jeddah, Saudi Arabia has funded this project, under grant no. (RG-49-135-40).

\section{References}

[1] S. Fang, Y. Wang, B. Gou, and Y. Xu, “Toward Future Green Maritime Transportation: An Overview of Seaport Microgrids and All-Electric Ships," IEEE Trans. Veh. Technol., vol. 69, no. 1, pp. 207-219, 2020, doi: 10.1109/TVT.2019.2950538.

[2] "Pioneers in clean energy," Ministry of Foreign Affairs of Denmark. https://denmark.dk/innovation-and-design/clean-energy.

[3] D. P. T. 70 P. C. R. U. W. Energy, “No Title," THE MARITIME EXECUTIVE, 2021. https://www.maritimeexecutive.com/article/danish-port-targets-70-percent-carbon-reduction-using-wind-energy.

[4] D. Mueller, S. Uibel, M. Takemura, D. Klingelhoefer, and D. A. Groneberg, “Ships, ports and particulate air pollution - An analysis of recent studies," J. Occup. Med. Toxicol., vol. 6, no. 1, pp. 1-6, 2011, doi: 10.1186/1745-6673-6-31.

[5] E. A. Sciberras, B. Zahawi, and D. J. Atkinson, "Electrical characteristics of cold ironing energy supply for berthed ships," Transp. Res. Part D Transp. Environ., vol. 39, pp. 31-43, 2015, doi: 10.1016/j.trd.2015.05.007.

[6] E. A. Sciberras, “Emission Reduction and Energy Control," no. March, 2016.

[7] D. Colarossi and P. Principi, "Technical analysis and economic evaluation of a complex shore-to-ship power supply system," 
Appl. Therm. Eng., vol. 181, p. 115988, 2020, doi: 10.1016/j.applthermaleng.2020.115988.

[8] N. N. A. Bakar, M. Y. Hassan, M. F. Sulaima, M. N. im Mohd Nasir, and A. Khamis, “Microgrid and load shedding scheme during islanded mode: A review," Renew. Sustain. Energy Rev., vol. 71, no. November 2016, pp. 161-169, 2017, doi: 10.1016/j.rser.2016.12.049.

[9] C. A. Reusser, "Evaluation of the Emission Impact of Cold-Ironing Power Systems, Using a Bi-Directional Power Flow Control Strategy," pp. 1-16, 2021.

[10] A. Roy, F. Auger, J. Olivier, E. Schae, and B. Auvity, “Microgrids in Harbor Areas : A Review,” pp. 1-24, 2020.

[11] T. Odun-ayo, “Scholars ' Mine Impact of stochastic loads and generations on power system transient stability," 2011.

[12] P. Xie et al., "Optimization-Based Power and Energy Management System in Shipboard Microgrid: A Review," IEEE Syst. J., pp. 1-13, 2021, doi: 10.1109/JSYST.2020.3047673.

[13] A. O. Rousis, D. Tzelepis, I. Konstantelos, C. Booth, and G. Strbac, "Design of a hybrid ac/dc microgrid using homer pro: Case study on an islanded residential application," Inventions, vol. 3, no. 3, pp. 1-14, 2018, doi: 10.3390/inventions3030055.

[14] M. G. Yenalem and P. Hinga, "Modelling and Optimal Sizing of Grid-Connected Micro grid System using HOMER in Bahir Dar City , Ethiopia 2 Literature Review," Int. J. Power Syst., vol. 5, pp. 1-12.

[15] H. Shahinzadeh, M. Moazzami, S. H. Fathi, and G. B. Gharehpetian, "Optimal sizing and energy management of a gridconnected microgrid using HOMER software," 2016 Smart Grids Conf. SGC 2016, no. December, pp. 13-18, 2017, doi: 10.1109/SGC.2016.7882945.

[16] P. Kumar, R. Pukale, N. Kumabhar, and U. Patil, “Optimal Design Configuration Using HOMER,” Procedia Technol., vol. 24, pp. 499-504, 2016, doi: 10.1016/j.protcy.2016.05.085.

[17] K. M. Krishna, “Optimization analysis of microgrid using HOMER - A case study,” Proc. - 2011 Annu. IEEE India Conf. Eng. Sustain. Solut. INDICON-2011, no. August, 2011, doi: 10.1109/INDCON.2011.6139566.

[18] V. Motjoadi, K. E. Adetunji, and P. K. Meera Joseph, "Planning of a sustainable microgrid system using HOMER software," 2020 Conf. Inf. Commun. Technol. Soc. ICTAS 2020 - Proc., pp. 0-4, 2020, doi: 10.1109/ICTAS47918.2020.233986.

[19] A. Yasin and M. Alsayed, “Optimization with excess electricity management of a PV, energy storage and diesel generator hybrid system using HOMER Pro software," Int. J. Appl. Power Eng., vol. 9, no. 3, p. 267, 2020, doi: 10.11591/ijape.v9.i3.pp267283.

[20] J. Lata-Garcì, C. Reyes-Lopez, F. Jurado, L. M. Fernández-Ramírez, and H. Sanchez, "Sizing optimization of a small hydro/photovoltaic hybrid system for electricity generation in Santay Island, Ecuador by two methods," 2017 Chil. Conf. Electr. Electron. Eng. Inf. Commun. Technol. CHILECON 2017 - Proc., vol. 2017-Janua, no. March 2018, pp. 1-6, 2017, doi: 10.1109/CHILECON.2017.8229539.

[21] N. B. Ahamad, M. Othman, J. C. Vasquez, J. M. Guerrero, and C. L. Su, “Optimal sizing and performance evaluation of a renewable energy based microgrid in future seaports," Proc. IEEE Int. Conf. Ind. Technol., vol. 2018-Febru, no. February, pp. 1043-1048, 2018, doi: 10.1109/ICIT.2018.8352322.

[22] M. Kharrich et al., "Optimal design of an isolated hybrid microgrid for enhanced deployment of renewable energy sources in Saudi Arabia," Sustain., vol. 13, no. 9, pp. 1-26, 2021, doi: 10.3390/su13094708.

[23] A. Innes and J. Monios, "Identifying the unique challenges of installing cold ironing at small and medium ports - The case of aberdeen," Transp. Res. Part D Transp. Environ., vol. 62, no. March, pp. 298-313, 2018, doi: 10.1016/j.trd.2018.02.004.

[24] N. B. B. Ahamad, J. M. Guerrero, C. L. Su, J. C. Vasquez, and X. Zhaoxia, “Microgrids Technologies in Future Seaports," Proc. - 2018 IEEE Int. Conf. Environ. Electr. Eng. 2018 IEEE Ind. Commer. Power Syst. Eur. EEEIC/I CPS Eur. 2018, pp. 1-6, 2018, doi: 10.1109/EEEIC.2018.8494428.

[25] A. M. A. Haidar, A. Fakhar, and A. Helwig, "Sustainable energy planning for cost minimization of autonomous hybrid microgrid using combined multi-objective optimization algorithm," Sustain. Cities Soc., vol. 62, no. December 2019, p. 102391, 
2020, doi: 10.1016/j.scs.2020.102391.

[26] G. Ciulla, A. D’Amico, V. Di Dio, and V. Lo Brano, “Modelling and analysis of real-world wind turbine power curves: Assessing deviations from nominal curve by neural networks," Renew. Energy, vol. 140, no. September 2020, pp. 477-492, 2019, doi: 10.1016/j.renene.2019.03.075.

[27] W. Wang, Y. Peng, X. Li, Q. Qi, P. Feng, and Y. Zhang, “A two-stage framework for the optimal design of a hybrid renewable energy system for port application," Ocean Eng., vol. 191, no. July, p. 106555, 2019, doi: 10.1016/j.oceaneng.2019.106555.

[28] Z. Zhou, M. Benbouzid, J. Frédéric Charpentier, F. Scuiller, and T. Tang, “A review of energy storage technologies for marine current energy systems," Renew. Sustain. Energy Rev., vol. 18, pp. 390-400, 2013, doi: 10.1016/j.rser.2012.10.006.

[29] G. Brando, A. Dannier, A. Del Pizzo, L. P. Di Noia, and C. Pisani, “Grid connection of wave energy converter in heaving mode operation by supercapacitor storage technology," IET Renew. Power Gener., vol. 10, no. 1, pp. 88-97, 2016, doi: 10.1049/iet-rpg.2015.0093. 